\title{
HIPERBILIRUBINEMIA PADA NEONATUS
}

\author{
${ }^{1}$ Stevry Mathindas \\ ${ }^{2}$ Rocky Wilar \\ ${ }^{2}$ Audrey Wahani
}

\author{
${ }^{1}$ Kandidat Skripsi Fakultas Kedokteran Universitas Sam Ratulangi Manado \\ ${ }^{2}$ Bagian Ilmu Kesehatan Anak Fakultas Kedokteran Universitas Sam Ratulangi Manado \\ Email:sp4rk_y@yahoo.com
}

\begin{abstract}
Hyperbilirubinemia is an increase of the blood bilirubin level due to physiological or nonphysiologic factors, which is clinically characterized by jaundice. Bilirubin is produced in the reticuloendothelial system as the end product of heme catabolism through an oxidation-reduction reaction. Due to its hydrophobic nature, unconjugated bilirubin is carried in the plasma, tightly bound to albumin. In the liver, bilirubin is transported into hepatocytes, bound to ligandin. After being excreted to the small intestine through the bile ducts, bilirubin undergoes a reduction to become colorless tetrapyrole due to the action of intestinal microbes. This unconjugated bilirubin can be reabsorbed into the circulation; therefore, it increases total plasma bilirubin. The treatments of hyperbilirubinemia in neonati are phototherapy, intravenous immunoglobulin (IVIG), replacement transfusion, temporary breastfeeding cessation, and medical therapy.
\end{abstract}

Keywords: hyperbilirubinemia, bilirubin, biliverdin, enterohepatic cycle.

\begin{abstract}
Abstrak: Hiperbilirubinemia ialah terjadinya peningkatan kadar bilirubin dalam darah, baik oleh faktor fisiologik maupun non-fisiologik, yang secara klinis ditandai dengan ikterus. Bilirubin diproduksi dalam sistem retikuloendotelial sebagai produk akhir dari katabolisme heme dan terbentuk melalui reaksi oksidasi reduksi. Karena sifat hidrofobiknya, bilirubin tak terkonjugasi diangkut dalam plasma, terikat erat pada albumin. Ketika mencapai hati, bilirubin diangkut ke dalam hepatosit, terikat dengan ligandin. Setelah diekskresikan ke dalam usus melalui empedu, bilirubin direduksi menjadi tetrapirol tak berwarna oleh mikroba di usus besar. Bilirubin tak terkonjugasi ini dapat diserap kembali ke dalam sirkulasi, sehingga meningkatkan bilirubin plasma total. Pengobatan pada kasus hiperbilirubinemia dapat berupa fototerapi, intravena immunoglobulin (IVIG), transfusi pengganti, penghentian ASI sementara, dan terapi medikamentosa.
\end{abstract}

Kata kunci: hiperbilirubinemia, bilirubin, biliverdin, siklus enterohepatik.

Hiperbilirubinemia merupakan salah satu fenomena klinis yang paling sering ditemukan pada bayi baru lahir. ${ }^{1}$ Lebih dari $85 \%$ bayi cukup bulan yang kembali dirawat dalam minggu pertama kehidupan disebabkan oleh keadaan ini. ${ }^{2}$ Bayi dengan hiperbilirubinemia tampak kuning akibat akumulasi pigmen bilirubin yang berwarna kuning pada sklera dan kulit. ${ }^{1,2}$

Pada janin, tugas mengeluarkan bilirubin dari darah dilakukan oleh plasenta, dan bukan oleh hati. Setelah bayi lahir, tugas ini langsung diambil alih oleh hati, yang memerlukan sampai beberapa minggu untuk penyesuaian. Selama selang waktu tersebut, hati bekerja keras untuk mengeluarkan bilirubin dari darah. Walaupun demikian, jumlah bilirubin yang tersisa masih menumpuk di dalam tubuh. Oleh karena bilirubin berwarna kuning, maka jumlah bilirubin yang berlebihan dapat memberi warna pada kulit, sklera, dan jaringan-jaringan tubuh lainnya. ${ }^{1-3}$

Pada setiap bayi yang mengalami 
ikterus harus dibedakan apakah ikterus yang terjadi merupakan keadaan yang fisiologik atau non-fisiologik. Selain itu, perlu dimonitor apakah keadaan tersebut mempunyai kecenderungan untuk berkembang menjadi hiperbilirubinemia berat yang memerlukan penanganan optimal. ${ }^{2-4}$

\section{HIPERBILIRUBINEMIA DAN IKTERUS}

Hiperbilirubinemia adalah keadaan dimana terjadi peningkatan kadar bilirubin dalam darah $>5 \mathrm{mg} / \mathrm{dL}$, yang secara klinis ditandai oleh adanya ikterus, dengan faktor penyebab fisiologik dan non-fisiologik. ${ }^{1,2,4}$

\section{Ikterus fisiologik}

Bentuk ikterus ini umumnya terjadi pada bayi baru lahir dengan kadar bilirubin tak terkonjugasi pada minggu pertama $>2$ $\mathrm{mg} / \mathrm{dL}$. Pada bayi cukup bulan yang diberi susu formula, kadar bilirubin akan mencapai puncaknya sekitar 6-8 mg/dl pada hari ke-3 kehidupan dan kemudian akan menurun cepat selama 2-3 hari diikuti dengan penurunan lambat sebesar $1 \mathrm{mg} / \mathrm{dL}$ selama 1 sampai 2 minggu. Pada bayi cukup bulan yang mendapat ASI, kadar bilirubin puncak akan mencapai kadar yang lebih tinggi (7-14 mg/dL) dan penurunan terjadi lebih lambat, bisa terjadi selama 2-4 minggu, bahkan dapat mencapai 6 minggu.
Pada bayi kurang bulan yang mendapat susu formula juga akan terjadi peningkatan kadar bilirubun dengan kadar puncak yang lebih tinggi dan bertahan lebih lama, demikian pula dengan penurunannya bila tidak diberikan fototerapi pencegahan. Peningkatan kadar billirubin sampai 10-12 $\mathrm{mg} / \mathrm{dl}$ masih dalam kisaran fisiologik, bahkan hingga $15 \mathrm{mg} / \mathrm{dL}$ tanpa disertai kelainan metabolism bilirubin., ${ }^{1,2,4}$

Frekuensi ikterus pada bayi cukup bulan dan kurang bulan ialah secara berurut 50-60\% dan 80\%. Umumnya fenomena ikterus ini ringan dan dapat membaik tanpa pengobatan. Ikterus fisiologik tidak disebabkan oleh faktor tunggal tetapi kombinasi dari berbagai faktor yang berhubungan dengan maturitas fisiologik bayi baru lahir. Peningkatan kadar bilirubin tidak terkonjugasi dalam sirkulasi bayi baru lahir disebabkan oleh kombinasi peningkatan ketersediaan bilirubin dan penurunan klirens bilirubin. ${ }^{1,2,4}$

\section{Ikterus non-fisiologik}

Jenis ikterus ini dahulu dikenal sebagai ikterus patologik, yang tidak mudah dibedakan dengan ikterus fisiologik. Terdapatnya hal-hal di bawah ini merupakan petunjuk untuk tindak lanjut, yaitu: ikterus yang terjadi sebelum usia 24 jam; setiap peningkatan kadar bilirubin serum yang memerlukan fototerapi; peningkatan kadar

Tabel 1. Faktor yang berhubungan dengan ikterus fisiologik. ${ }^{2}$

\begin{tabular}{ll}
\hline \multicolumn{1}{c}{ Dasar } & \multicolumn{1}{c}{ Penyebab } \\
\hline $\begin{array}{l}\text { Peningkatan bilirubin yang tersedia } \\
\text { Peningkatan produksi bilirubin }\end{array}$ & $\begin{array}{l}\text { Peningkatan jumlah sel darah merah } \\
\text { Penurunan umur sel darah merah } \\
\text { Peningkatan early bilirubin } \\
\text { Peningkatan aktivitas ß-glukoronidase }\end{array}$ \\
$\begin{array}{ll}\text { Peningkatan resirkulasi melalui } \\
\text { shunt }\end{array}$ & $\begin{array}{l}\text { Tidak adanya flora bakteri } \\
\text { Pengeluaran mekonium yang terlambat }\end{array}$ \\
& $\begin{array}{l}\text { Defisiensi protein karier } \\
\text { Penurunan klirens bilirubin }\end{array}$ \\
$\begin{array}{l}\text { Penurunan klirens dari plasma } \\
\text { Penurunan metabolisme hati }\end{array}$ & Penurunan aktifitas UDPG \\
\hline
\end{tabular}


bilirubin total serum $>0,5 \mathrm{mg} / \mathrm{dL} / \mathrm{jam}$; adanya tanda-tanda penyakit yang mendasar pada setiap bayi (muntah, letargis, malas menetek, penurunan berat badan yang cepat, apnea, takipnea, atau suhu yang tidak stabil); ikterus yang bertahan setelah delapan hari pada bayi cukup bulan atau setelah 14 hari pada bayi kurang bulan. ${ }^{5,6}$

\section{Metabolisme bilirubin}

Sebagian besar produksi bilirubin merupakan akibat degradasi hemoglobin pada sistem retikuloendotelial. Tingkat penghancuran hemoglobin pada neonatus lebih tinggi daripada bayi yang lebih tua. Sekitar $1 \mathrm{~g}$ hemoglobin dapat menghasilkan $35 \mathrm{mg}$ bilirubin indirek, yaitu bilirubin yang larut dalam lemak tetapi tidak larut dalam air. ${ }^{7,8}$

Transportasi bilirubin indirek melalui ikatan dengan albumin. Bilirubin ditransfer melalui membran sel ke dalam hepatosit, sedangkan albumin tidak. Di dalam sel, bilirubin akan terikat pada ligandin, serta sebagian kecil pada glutation S-transferase lain dan protein Z. Proses ini merupakan proses dua arah, tergantung dari konsentrasi dan afinitas albumin plasma dan ligandin dalam hepatosit. Sebagian besar bilirubin yang masuk hepatosit dikonjugasi dan diekskresi ke dalam empedu. Di dalam sitosol hepatosit, ligandin mengikat bilirubin sedangkan albumin tidak. ${ }^{7,8}$

Di dalam hepatosit terjadi konjugasi lanjut dari bilirubin menjadi bilirubin diglukoronid. Sebagian kecil bilirubin terdapat dalam bentuk monoglukoronid, yang akan diubah oleh glukoronil-transferase menjadi diglukorinid. Enzim yang terlibat dalam sintesis bilirubin diglukorinid, yaitu uridin difosfat-glukoronid transferase (UDPG-T), yang mengatalisis pembentukan bilirubin monoglukoronid. Sintesis dan ekskresi diglukoronid terjadi di kanalikuli empedu. Isomer bilirubin yang dapat membentuk ikatan hidrogen seperti bilirubin natural IX dapat diekskresi langsung ke dalam empedu tanpa konjugasi, misalnya isomer yang terjadi sesudah terapi sinar. Setelah konjugasi bilirubin menjadi bilirubin direk yang larut dalam air, terjadi ekskresi segera ke sistem empedu kemudian ke usus. Di dalam usus, bilirubin direk ini tidak di absorbsi; sebagian bilirubin direk dihidrolisis menjadi bilirubin indirek dan direabsorbsi, siklus ini disebut siklus enterohepatik. ${ }^{7,8}$

\section{Etiologi ikterus}

Etiologi ikterus yang sering ditemukan ialah: hiperbilirubinemia fisiologik, inkompabilitas golongan darah ABO dan Rhesus, breast milk jaundice, infeksi, bayi dari ibu penyandang diabetes melitus, dan polisitemia/hiperviskositas.

Etiologi yang jarang ditemukan yaitu: defisiensi G6PD, defisiensi piruvat kinase, sferositosis kongenital, sindrom LuceyDriscoll, penyakit Crigler-Najjar, hipotiroid, dan hemoglobinopati.

\section{Patofisiologi}

Bilirubin diproduksi dalam sistem retikuloendotelial sebagai produk akhir dari katabolisme heme dan terbentuk melalui reaksi oksidasi reduksi. Pada langkah pertama oksidasi, biliverdin terbentuk dari heme melalui kerja heme oksigenase, dan terjadi pelepasan besi dan karbon monoksida. Besi dapat digunakan kembali, sedangkan karbon monoksida diekskresikan melalui paru-paru. ${ }^{2,3,10}$ Biliverdin yang larut dalam air direduksi menjadi bilirubin yang hampir tidak larut dalam air dalam bentuk isomerik (oleh karena ikatan hidrogen intramolekul). Bilirubin tak terkonjugasi yang hidrofobik diangkut dalam plasma, terikat erat pada albumin. ${ }^{2,10,11}$ Bila terjadi gangguan pada ikatan bilirubin tak terkonjugasi dengan albumin baik oleh faktor endogen maupun eksogen (misalnya obatobatan), bilirubin yang bebas dapat melewati membran yang mengandung lemak (double lipid layer), termasuk penghalang darah otak, yang dapat mengarah ke neurotoksisitas. ${ }^{2,3,10}$

Bilirubin yang mencapai hati akan diangkut ke dalam hepatosit, dimana bilirubin terikat ke ligandin. Masuknya bilirubin ke hepatosit akan meningkat sejalan dengan 
terjadinya peningkatan konsentrasi ligandin. Konsentrasi ligandin ditemukan rendah pada saat lahir namun akan meningkat pesat selama beberapa minggu kehidupan. ${ }^{2,3,10}$

Bilirubin terikat menjadi asam glukuronat di retikulum endoplasmik retikulum melalui reaksi yang dikatalisis oleh uridin difosfoglukuronil transferase (UDPGT). Konjugasi bilirubin mengubah molekul bilirubin yang tidak larut air menjadi molekul yang larut air. Setelah diekskresikan kedalam empedu dan masuk ke usus, bilirubin direduksi dan menjadi tetrapirol yang tak berwarna oleh mikroba di usus besar. Sebagian dekonjugasi terjadi di dalam usus kecil proksimal melalui kerja B-glukuronidase. Bilirubin tak terkonjugasi ini dapat diabsorbsi kembali dan masuk ke dalam sirkulasi sehingga meningkatkan bilirubin plasma total. Siklus absorbsi, konjugasi, ekskresi, dekonjugasi, dan reabsorbsi ini disebut sirkulasi enterohepatik. Proses ini berlangsung sangat panjang pada neonatus, oleh karena asupan gizi yang terbatas pada hari-hari pertama kehidupan. ${ }^{2,3,10}$

\section{Faktor risiko}

\section{ASI yang kurang}

Bayi yang tidak mendapat ASI cukup saat menyusui dapat bermasalah karena tidak cukupnya asupan ASI yang masuk ke usus untuk memroses pembuangan bilirubin dari dalam tubuh. Hal ini dapat terjadi pada bayi prematur yang ibunya tidak memroduksi cukup ASI. ${ }^{11}$

\section{Peningkatan jumlah sel darah merah}

Peningkatan jumlah sel darah merah dengan penyebab apapun berisiko untuk terjadinya hiperbilirubinemia. Sebagai contoh, bayi yang memiliki jenis golongan darah yang berbeda dengan ibunya, lahir dengan anemia akibat abnormalitas eritrosit (antara lain eliptositosis), atau mendapat transfusi darah; kesemuanya berisiko tinggi akan mengalami hiperbilirubinemia. ${ }^{11,12}$

\section{Infeksi/ inkompabilitas ABO-Rh}

Bermacam infeksi yang dapat terjadi pada bayi atau ditularkan dari ibu ke janin di dalam rahim dapat meningkatkan risiko hiperbilirubinemia. Kondisi ini dapat meliputi infeksi kongenital virus herpes, sifilis kongenital, rubela, dan sepsis. ${ }^{11,12}$

\section{Gejala klinis pada hiperbillirubinemia}

Sebagian besar kasus hiperbilirubinemia tidak berbahaya, tetapi kadangkadang kadar bilirubin yang sangat tinggi bisa menyebabkan kerusakan otak (Kern icterus). Gejala klinis yang tampak ialah rasa kantuk, tidak kuat menghisap ASI/susu formula, muntah, opistotonus, mata terputar-putar keatas, kejang, dan yang paling parah bisa menyebabkan kematian. Efek jangka panjang Kern icterus ialah retardasi mental, kelumpuhan serebral, tuli, dan mata tidak dapat digerakkan ke atas. ${ }^{13,14}$

\section{DIAGNOSIS}

\section{Visual}

Metode visual memiliki angka kesalahan yang cukup tinggi, namun masih dapat digunakan bila tidak tersedia alat yang memadai. Pemeriksaan ini sulit diterapkan pada neonatus kulit berwarna, karena besarnya bias penilaian. Secara evident base, pemeriksaan metode visual tidak direkomendasikan, namun bila terdapat keterbatasan alat masih boleh digunakan untuk tujuan skrining. Bayi dengan skrining positif harus segera dirujuk untuk diagnosis dan tata laksana lebih lanjut. ${ }^{2,3}$

Panduan WHO mengemukakan cara menentukan ikterus secara visual, sebagai berikut: ${ }^{2,3}$

1. Pemeriksaan dilakukan pada pencahayaan yang cukup (di siang hari dengan cahaya matahari) karena ikterus bisa terlihat lebih parah bila dilihat dengan pencahayaan buatan dan bisa tidak terlihat pada pencahayaan yang kurang.

2. Kulit bayi ditekan dengan jari secara lembut untuk mengetahui warna di bawah kulit dan jaringan subkutan.

3. Keparahan ikterus ditentukan berdasarkan usia bayi dan bagian tubuh yang tampak kuning. 


\section{Bilirubin serum}

Pemeriksaan bilirubin serum merupakan baku emas penegakan diagnosis ikterus neonatorum serta untuk menentu-kan perlunya intervensi lebih lanjut. Pelaksanaan pemeriksaan serum bilirubin total perlu dipertimbangkan karena hal ini merupakan tindakan invasif yang dianggap dapat meningkatkan morbiditas neonatus. ${ }^{2,3}$

\section{Bilirubinometer transkutan}

Bilirubinometer merupakan instrumen spektrofotometrik dengan prinsip kerja memanfaatkan bilirubin yang menyerap cahaya (panjang gelombang $450 \mathrm{~nm}$ ). Cahaya yang dipantulkan merupakan representasi warna kulit neonatus yang sedang diperiksa. ${ }^{2,3}$

\section{Pemeriksaan bilirubin bebas dan CO}

Bilirubin bebas dapat melewati sawar darah otak secara difusi. Oleh karena itu, ensefalopati bilirubin dapat terjadi pada konsentrasi bilirubin serum yang rendah. ${ }^{2,3}$

Beberapa metode digunakan untuk mencoba mengukur kadar bilirubin bebas, antara lain dengan metode oksidaseperoksidase. Prinsip cara ini yaitu berdasarkan kecepatan reaksi oksidasi peroksidasi terhadap bilirubin dimana bilirubin menjadi substansi tidak berwarna. Dengan pendekatan bilirubin bebas, tata laksana ikterus neonatorum akan lebih terarah. ${ }^{2,3}$

Pemecahan heme menghasilkan bilirubin dan gas $\mathrm{CO}$ dalam jumlah yang ekuivalen. Berdasarkan hal ini, maka pengukuran konsentrasi CO yang dikeluarkan melalui pernapasan dapat digunakan sebagai indeks produksi bilirubin.,

\section{Diagnosis banding ${ }^{3,14}$}

Sebagai diagnosis banding dari ikterus yaitu: atresia bilier, breast milk jaundice, kolestasis, anemia hemolitik pada bayi baru lahir, hepatitis B, dan hipotiroid.

\section{PENGOBATAN}

\section{Fototerapi}

Fototerapi dapat digunakan tunggal atau dikombinasi dengan transfusi pengganti untuk menurunkan bilirubin. Bila neonatus dipapar dengan cahaya berintensitas tinggi, tindakan ini dapat menurunkan bilirubin dalam kulit. Secara umum, fototerapi harus diberikan pada kadar bilirubin indirek 4-5 mg/dl. Neonatus yang sakit dengan berat badan kurang dari 1000 gram harus difototerapi bila konsentrasi bilirubin $5 \mathrm{mg} / \mathrm{dl}$. Beberapa pakar mengarahkan untuk memberikan fototerapi profilaksis 24 jam pertama pada bayi berisiko tinggi dan berat badan lahir rendah. ${ }^{15,17}$

\section{Intravena immunoglobulin (IVIG)}

Pemberian IVIG digunakan pada kasus yang berhubungan dengan faktor imunologik. Pada hiperbilirubinemia yang disebabkan oleh inkompatibilitas golongan darah ibu dan bayi, pemberian IVIG dapat menurunkan kemungkinan dilakukannya transfusi tukar. ${ }^{3,16}$

\section{Transfusi pengganti}

Transfusi pengganti digunakan untuk mengatasi anemia akibat eritrosit yang rentan terhadap antibodi erirtosit maternal; menghilangkan eritrosit yang tersensitisasi; mengeluarkan bilirubin serum; serta meningkatkan albumin yang masih bebas bilirubin dan meningkatkan keterikatannya dangan bilirubin. ${ }^{3,16}$

\section{Penghentian ASI}

Pada hiperbilirubinemia akibat pemberian ASI, penghentian ASI selama 24-48 jam akan menurunkan bilirubin serum. Mengenai pengentian pemberian ASI (walaupun hanya sementara) masih terdapat perbedaan pendapat. ${ }^{3,16}$

\section{Terapi medikamentosa}

Phenobarbital dapat merangsang hati untuk menghasilkan enzim yang meningkatkan konjugasi bilirubin dan mengekskresikannya. Obat ini efektif diberikan pada ibu hamil selama beberapa hari sampai beberapa minggu sebelum melahirkan. 
Penggunaan phenobarbital post natal masih menjadi pertentangan oleh karena efek sampingnya (letargi). Coloistrin dapat mengurangi bilirubin dengan mengeluarkannya melalui urin sehingga dapat menurunkan kerja siklus enterohepatika. ${ }^{3,15,16}$

\section{SIMPULAN}

Hiperbilirubinemia adalah keadaan dimana terjadi peningkatan kadar bilirubin $>5 \mathrm{mg} / \mathrm{dL}$ pada darah, yang sering ditandai oleh adanya ikterus. Pada bayi baru lahir, hiperbilirubinemia sering terjadi oleh karena kemampuan hati bayi yang masih kurang untuk mengekskresikan bilirubin yang terus diproduksi.

Etiologi hiperbilirubunemia perlu dideteksi secara pasti, fisiologik atau nonfisiologik, sebagai dasar pemeriksaan dan tindak lanjut penanganan neonatus.

Pengobatan hiperbilirubinemia bertujuan untuk menurunkan kadar bilirubin yang tinggi. Pemantauan dan pemeriksaan yang tepat sangat dibutuhkan untuk menentukan jenis pengobatan yang akan dipergunakan.

\section{DAFTAR PUSTAKA}

1. Wong RJ, Stevenson DK, Ahlfors CE, Vreman HJ. Neonatal Jaundice: Bilirubin physiology and clinical chemistry. NeoReviews 2007;8:58-67.

2. Sukadi A. Hiperbilirubinemia. In: Kosim MS, Yunanto A, Dewi R, Sarosa GI, Usman A, penyunting. Buku Ajar Neonatologi (Edisi Ke-1). Jakarta: Ikatan Dokter Anak Indonesia, 2010; p. 147-53.

3. Hansen TWR. Jaundice, neonatal. E. Medicine [homepage on the Internet]. 2011 [updated 2011 June 15; cited 2011 October 15]. Available from: http://www.emedicine.medscape.com/a rticle/974786-overview.

4. Halamek LP, Stevenson DK. Neonatal jaundice and liver disease. In: Fanaroff AA, Martin RJ, editors. Neonatalperinatal Medicine. Disease of the Fetus and Infant (Seventh Edition). St Louis: Mosby Inc, 2002; p.1309-50.

5. Martin CR, Cloherty JP. Neonatal hyperbilirubinemia. In: Cloherty JP, Eichenwaald EC, Stark AR, editors. Manual of Neonatal Care (Fifth Edition). Philadelphia: Lippincott Williams \& Wilkins. 2004; p.185-221.

6. Monagan T. Hyperbilirubinemia risk factors [homepage on the Internet]. 2010 [updated 2010 Mei 6; cited 2011 Oktober 15]. Available from: http://www.livestrong.com/article/1400 65-hyperbilirubinemia-risk-factors/.

7. Maisels MJ. Neonatal Hyperbilirubinemia. In: Klaus MH, Fanaroff AA, editors. Care of the High-Risk Neonate (Fifth Edition). Philadelphia: WB Saunders Co, 2001; p.324-62.

8. Behrman RE, Kliegman RM, Jenson HB, editors. Nelson Textbook of Pediatrics (17th Edition). Philadelphia PA: Saunders; 2004.

9. Porter ML, Dennis BL. Hyperbilirubinemia in the term newborn. American Family Physician. 2002; 65:599-606.

10. Gomella TL, Cunningham MD, Eyal FG, Zenk KE. Hyperbilirubinemia. In: Gomella TL, editor. Neonatology; Management procedures, on-call problems, disease and drugs. New York: Lange Medical Book/McGrawHill Co, 2004; p.381-95.

11. Hiperbilirubinemia. [homepage on the internet]. Nodate [updated 02 February 2010; cited 2011 October 15]. Available from: http://forum.um.ac.id/ index.php? topic $=8421.0$.

12. Hiperbilirubinemia. [homepage on the internet]. Nodate [cited 2011 Oktober 15]: Available from: http://medica store.com/penyakit/392/Hiperbilirubine mia.

13. Mengenal ikterus neonatorum. [homepage on the internet]. Nodate [cited 2011 Oktober 17]. Available from: http://www.smallcrab.com/anak-anak/ 535-mengenal-ikterus-neonatorum.

14. American Academy of Pediatrics. Subcommitteee on hyperbilirubinemia. Management of hyperbilirubinemia in the newborn infant 35 or more weeks of gestation. Clinical Practice Guidelines. Pediatrics. 2004;114:297-316.

15. Emedicine. Ikterus pada neonatus [homepage on the Internet]. 2010 [cited 2011 Oktober 17]. Available from: http://tumbuhsehat.com/index. 
S10 Jurnal Biomedik, Volume 5, Nomor 1, Suplemen, Maret 2013, hlm. S4-10

php?option=com-content\&view=article

\&id=124\&itemid $=77$.

16. Ramasethu J. Neonatal Hyperbilirubinemia.
Neonatal Intensive Care Workshop, Jakarta: RSAB Harapan Kita; 2002. 